\title{
The Empirical Inquiry between Organizational Commitment and Employee Performance - with X Company as an Example
}

\author{
Xiaoqi Sheng ${ }^{1}$ \\ ${ }^{1}$ School of management, Shanghai University of engineering science, Shanghai 201620, China \\ Correspondence: Xiaoqi Sheng, School of management, Shanghai University of engineering science, Shanghai \\ 201620, China. E-mail: smilewy1314@126.com
}

Received: February 21, 2014

Accepted: April 9, 2014

Online Published: April 15, 2014

doi:10.5430/jbar.v3n1p59

URL: http://dx.doi.org/10.5430/jbar.v3n1p59

\begin{abstract}
In the context of economic globalization, the key of the enterprise's sustainable development is the rational utilization of human resources, to enhance the employee's job performance and form core competitiveness. In the many factors that affect employee performance, employee attitude has always been the focus of many researchers at home and abroad. This study selects an important aspect of employee attitude, organizational commitment, to explore the effect of organizational commitment in employee performance. However, most previous research studies respectively employee performance and organizational commitment. In order to explore the relationship between organizational commitment and employee performance, this paper analyzes the relationship on the basis of summarizing the predecessors' research, and applies the results of study to the practice, to provide the reference to the enterprise human resources management.

The paper is based on the samples consisted of 206 employees in X company, and use the empirical research methods, to explore the relationship between organizational commitment and job performance. The conclusion is: the organization normative commitment, ideal commitment, and economic commitment are positively correlated, and the opportunity commitment is a negatively correlation. The emotional commitment is not obvious, except that few employees' emotional commitment is related with the employee performance.
\end{abstract}

Keywords: Organizational commitment, Employee performance, Human resource, Data analysis

\section{Introduction}

\subsection{Research background}

After the reform and opening up, China's economy and business types develop rapidly, At the same time, as China's integration with the world economy, more and more foreign companies settle in the country, and multinational corporations also have a place in China's economic development gradually. In the background of globalization of information and the knowledge economy, enterprise resources can be fully mixed, and all enterprises can use the world's human and material resources. Since the 2008 financial crisis, the world economy has been suffering a serious setback, and there is more intense competition among enterprises. Therefore, the companies need to improve the performance of enterprise employees to enhance their competitiveness in the global economy. Organizational commitment reflects employees' organizational commitment and the loyalty of employees of enterprises, so that it can affect employees' performance in enterprises. So, in an increasingly competitive economic environment, analyzing how to improve organizational commitment of employees, in order to enhance employee performance, is of great significance.

\subsection{Research ideas}

In order to explore the relationship between organizational commitment and employee performance, this paper first analyzes the relationship from the theory aspect. The article introduces the related concepts of organizational commitment and some research about the relationship between the two. Then in the second chapter, we make empirical analysis on the data which are obtained by questionnaires in X Company, so as to explore the quantitative relationship between organizational commitment and employee performance. At last, we summarize the above analysis and propose some relevant suggestions on human resources development for X Company. Through the analysis of this article, we can further clarify the relationship between organizational commitment and employee performance, and provide a frame of reference to develop better human resources development strategies for large 
companies.

\subsection{Literature review}

Organizational commitment, this concept was first proposed by Howard Becker (1960).He thought that organizational commitment exists because the inputs of the staffs in the organization are hidden. With the time passing away, the investment of the staffs will increase, and if they left, they will lose the investment before, so they have to stay in the organization. This is actually a single input theory. The implicit inputs are unilateral, and they can refer to all things of value, such as welfare, energy and some skills which are used only in specific organizations. The concept of organizational commitment of this stage is given from the aspects of organizational behavior. After this, more and more scholars begin to inquiry organizational commitment, and analyze the relationship between organizational commitment and employee performance.

Dubin found that employee performance will increase as organizational commitment becomes higher. Fukami and Larson through relevant research indicates that organizational commitment can be said to be a very important predictor of job performance, and that the higher organizational commitment will lead to higher job performance. But Steers shows that there is no direct relationship between organizational commitment and employee performance through the empirical research. Bernard believes that the organizational normative commitment and affective commitment have significant impacts on all aspects of employee performance, but it is worth noting that the effectiveness of its continued commitment to the promotion and interpersonal staff both preached negative correlation. In addition, Haekett presented their research results that normative commitment has no relationship with the work performance of employees. But Ashfortll\&Saks points out in his conclusion, that normative commitment is positively correlated with total performance.

In 2005, Jaramillo regarded enterprise salesmen as the research object, and researched and analyzed the relationship between organizational commitment and job performance .He found, if their organizational commitment is higher, their work performances are better. At the same time, they also found in collectivism culture, the relationship between organizational commitment and employee performance is stronger than in the individual background.

In 2007, Han Yi used the four-dimensional mode about the work performance developed by one to do the empirical research about the effects of organizational commitment on job performance. And the regression analysis results show that, the organizational commitment has a significant impact with the four factors of job performance. If the level of employees' organizational commitment is higher, it will bring more significant job performance.

In summary, there are still some differences in the domestic study about the relations between organizational commitment and job performance. And just because of this, we need to study it more, to further explore the relationship between them.

\section{The empirical analysis of the relationship between organizational commitment and employee performance}

\subsection{The purpose of the empirical analysis}

In this paper, we regard X company as an example to examine the enterprise staff's organizational commitment level and analyze the relationship between organizational commitment and employee performance. At the same time, we will analyze the influence factors of both, and provide a reference basis for the company to develop human resource policies.

\subsection{The object of the empirical analysis}

$\mathrm{X}$ Company is a multinational corporation whose main services are large supermarkets and restaurants, and is one of the world's ten biggest retailer. Now it has branch offices in more than 10 countries and regions, more than 200 thousand employees, and 1.3 billion customers, and it is an us-funded enterprise in the world. Since X Company entered in China, it has provided the high quality service for thousands of Chinese customers, so it is deeply loved by customers.

This paper samples are mainly from the employees in one branch of X Company in China. There are 500 questionnaires. We recycled 280 questionnaires, and the recovery rate is $56 \%$, of which 206 questionnaires are valid samples, so the effective rate is $73.6 \%$. The basic characteristics of sample summary in table 1 : 
Table 1. the basic characteristics of respondents' summary

\begin{tabular}{|c|c|c|c|c|}
\hline category & sample distribution & number of samples & the percentage & total \\
\hline \multirow{2}{*}{ gender } & $\operatorname{man}$ & 108 & $52.4 \%$ & \multirow{2}{*}{206} \\
\hline & woman & 98 & $47.6 \%$ & \\
\hline \multirow{3}{*}{ age } & Under 25 & 127 & $61.6 \%$ & \multirow{3}{*}{206} \\
\hline & $26 \sim 40$ & 70 & $34.0 \%$ & \\
\hline & Above 40 & 9 & $4.4 \%$ & \\
\hline \multirow{4}{*}{$\begin{array}{l}\text { educational } \\
\text { background }\end{array}$} & $\begin{array}{l}\text { High school and the } \\
\text { following }\end{array}$ & 98 & $47.6 \%$ & \multirow{4}{*}{206} \\
\hline & junior college & 75 & $36.4 \%$ & \\
\hline & University degree & 32 & $15.5 \%$ & \\
\hline & Graduate or above & 1 & $0.5 \%$ & \\
\hline \multirow{4}{*}{ working life } & the following year & 51 & $24.7 \%$ & \multirow{4}{*}{206} \\
\hline & One to five years & 80 & $38.8 \%$ & \\
\hline & In five to ten years & 64 & $31.0 \%$ & \\
\hline & More than a decade & 11 & $5.5 \%$ & \\
\hline \multirow{4}{*}{ jobs } & Ordinary employees & 139 & $67.5 \%$ & \multirow{4}{*}{206} \\
\hline & First-line managers & 51 & $24.7 \%$ & \\
\hline & Middle managers & 12 & $5.8 \%$ & \\
\hline & Top managers & 4 & $2.0 \%$ & \\
\hline
\end{tabular}

By statistics, 108 men, (52.4\%), female, 98 people, accounting for $47.6 \%$, so the number of men is slightly more than women; In terms of the age distribution of the sample, the people who is under the age of 40 accounted for most, and among them, 127 people under the age of 25, 26-40, 70 people, the two ages accounted for $95.6 \%$; Degree structure, give priority to the people with high school education, accounting for $47.6 \%$; College graduate or bachelor degree accounted for 51.9\%; From the point of working years, employees of one to ten years accounted for $69.8 \%$; From the point of the positions, the number of ordinary people is a majority, $67.5 \%$, followed by first-line managers, accounting for $24.7 \%$; Comprehensive the above analysis about the characteristics of the effective sample, it can be seen that the questionnaire sampling distribution is evener, therefore, the effect of sampling is good.

\subsection{The empirical analysis of the data}

\subsubsection{The reliability analysis of questionnaires}

As we know, in order to guarantee the reliability and stability of the questionnaire, the reliability test needs to be done. It is generally believed that if a coefficient value is in 0.7 above, the reliability of this scale is acceptable. The higher reliability of a scale, the more stable the scale is. Processing on a questionnaire, the reliability analysis is shown in figure 1:

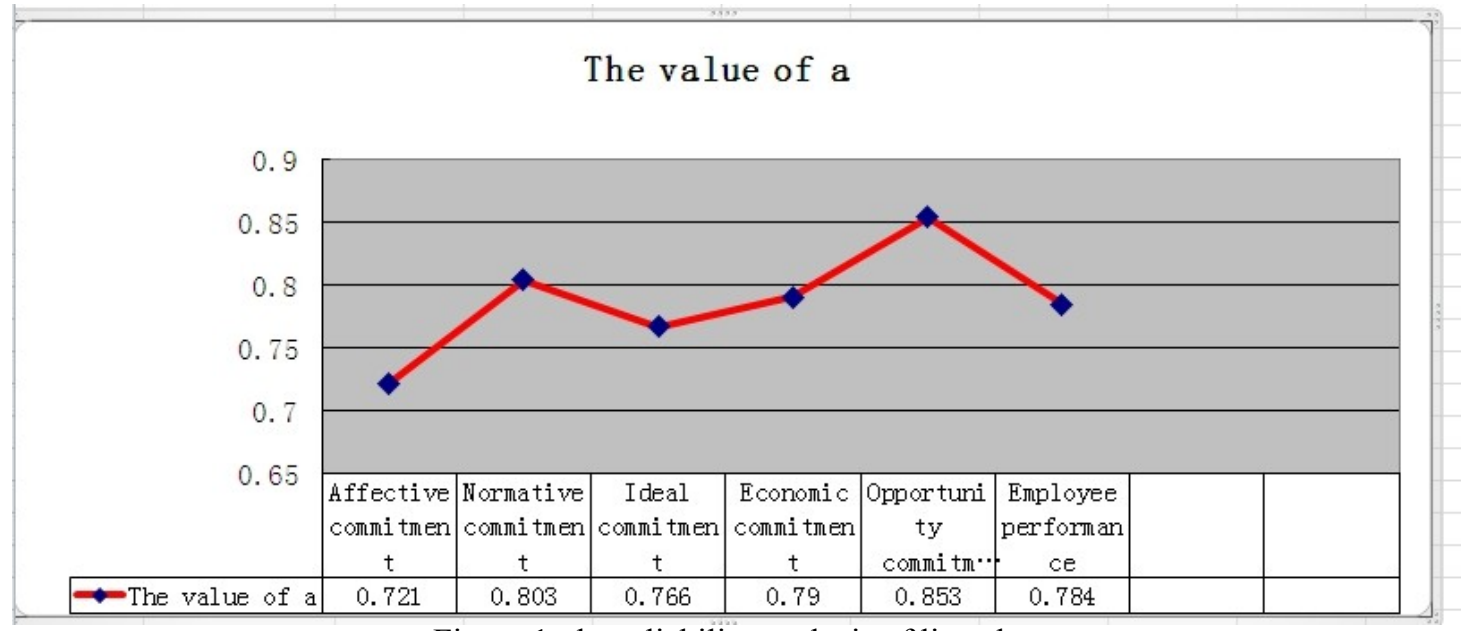

Figure 1 . the reliability analysis of line chart 
By the inspection results in the figure 1, we can see that the part reliabilities of the organizational commitment scale and job performance scale are higher than 0.7 standards, and it shows high reliability and consistency, namely the ideal of the reliability of the questionnaire.

\subsubsection{One-way ANOVA}

Reference the Minnesota satisfaction questionnaire (MSQ), we collected data from X company's questionnaires and got the employee's organizational commitment level. Using 5 points marking system, including: it means "strongly agree", 1 meter; Said "strongly disagree" and 5 points. Intermediate level meter, respectively, 2, 3, 4 points, according to the scoring method for dealing with problems, and calculate the employees' organizational commitment and job performance level.

In order to study whether or not the different demographic variables' (gender, education background, working life, jobs) effect on organizational commitment and job performance will produce differences, we can through the single factor analysis of variance to get the results. If the influence of the variable significant is 0.05 or less, we consider the significant differences. If the influence of the variable significant $>0.05$, we argue that there is no significant difference between the influences of the variable factor to this.

(1) The single factor analysis of gender

For researching that whether X company employee gender's impact on organizational commitment and employee performance exist a difference or not, we regard gender as a single variable, and do single factor analysis of organizational commitment and job performance. The results, as shown in the table, can be seen from in table 2.We can see that the employees' gender factors on the organizational commitment and employee performance impact did not differ significantly. At the same time the results reflect the female's emotional commitment and opportunity commitment level is slightly higher than the male; and male's ideal commitment, normative commitment, and economic commitment level is higher than women.

Table 2. single factor analysis of the gender scale

\begin{tabular}{|c|c|c|c|c|c|}
\hline The research project & gender & $\begin{array}{l}\text { number } \\
\text { samples }\end{array}$ & The mean & $\begin{array}{l}\text { The standard } \\
\text { deviation }\end{array}$ & $\begin{array}{l}\text { The } \\
\text { significant }\end{array}$ \\
\hline \multirow{2}{*}{$\begin{array}{l}\text { Affective } \\
\text { commitment }\end{array}$} & man & 108 & 2.139 & 0.901 & \multirow{2}{*}{0.109} \\
\hline & woman & 98 & 2.082 & 0.732 & \\
\hline \multirow{2}{*}{$\begin{array}{l}\text { Normative } \\
\text { commitment }\end{array}$} & $\operatorname{man}$ & 108 & 1.153 & 1.117 & \multirow[b]{2}{*}{0.361} \\
\hline & woman & 98 & 1.652 & 0.720 & \\
\hline \multirow{2}{*}{ Ideal commitment } & $\operatorname{man}$ & 108 & 1.854 & 1.111 & \multirow{2}{*}{0.418} \\
\hline & woman & 98 & 1.890 & 0.933 & \\
\hline \multirow{2}{*}{$\begin{array}{l}\text { The economic } \\
\text { commitment }\end{array}$} & $\operatorname{man}$ & 108 & 1.798 & 0.514 & \multirow[b]{2}{*}{0.722} \\
\hline & woman & 98 & 1.816 & 0.782 & \\
\hline \multirow{2}{*}{$\begin{array}{l}\text { Opportunity } \\
\text { commitment }\end{array}$} & $\operatorname{man}$ & 108 & 2.062 & 0.755 & \multirow{2}{*}{0.410} \\
\hline & woman & 98 & 1.999 & 1.257 & \\
\hline \multirow{2}{*}{$\begin{array}{l}\text { Employee } \\
\text { performance }\end{array}$} & man & 108 & 2.046 & 0.713 & \multirow{2}{*}{0.701} \\
\hline & woman & 98 & 1.916 & 1.032 & \\
\hline
\end{tabular}

Note: the mean column value is smaller, and the corresponding level is higher

(2) The single factor analysis of education

For researching that whether X company employee education's impact on organizational commitment and employee performance exist a difference or not, we regard education as a single variable, and do single factor analysis of organizational commitment and job performance. The results, as shown in the table, can be seen from in table 3.We can see that the employees' education factor on the organizational commitment and employee performance impact has obvious difference in ideal commitment, opportunity commitment and employee performance, and in terms of 
affective commitment, normative commitment, economic commitment without significant difference. With the increasing of education degree, they have a stronger desire in the enterprise to realize his ideal, so the ideal commitment is higher.

Table 3. single factor analysis of the education scale

\begin{tabular}{|c|c|c|c|c|c|}
\hline $\begin{array}{l}\text { The research } \\
\text { project }\end{array}$ & $\begin{array}{l}\text { Educational } \\
\text { background }\end{array}$ & $\begin{array}{l}\text { number } \\
\text { samples }\end{array}$ & The mean & $\begin{array}{l}\text { The standard } \\
\text { deviation }\end{array}$ & $\begin{array}{l}\text { The } \\
\text { significant }\end{array}$ \\
\hline \multirow{4}{*}{$\begin{array}{l}\text { Affective } \\
\text { commitment }\end{array}$} & $\begin{array}{l}\text { High school and } \\
\text { the following }\end{array}$ & 98 & 1.946 & 0.286 & \multirow{4}{*}{0.322} \\
\hline & junior college & 75 & 2.007 & 0.153 & \\
\hline & University degree & 32 & 1.973 & 0.119 & \\
\hline & Graduate or above & 1 & 1.982 & 0.180 & \\
\hline \multirow{4}{*}{$\begin{array}{l}\text { Normative } \\
\text { commitment }\end{array}$} & $\begin{array}{l}\text { High school and } \\
\text { the following }\end{array}$ & 98 & 1.315 & 0.244 & \multirow{4}{*}{0.526} \\
\hline & junior college & 75 & 1.510 & 0.162 & \\
\hline & University degree & 32 & 1.422 & 0.264 & \\
\hline & Graduate or above & 1 & 1.501 & 0.205 & \\
\hline \multirow{4}{*}{$\begin{array}{l}\text { Ideal } \\
\text { commitment }\end{array}$} & $\begin{array}{l}\text { High school and } \\
\text { the following }\end{array}$ & 98 & 2.167 & 0.364 & \multirow{4}{*}{0.002} \\
\hline & junior college & 75 & 2.091 & 0.251 & \\
\hline & University degree & 32 & 1.862 & 0.171 & \\
\hline & Graduate or above & 1 & 1.661 & 0.279 & \\
\hline \multirow{4}{*}{$\begin{array}{l}\text { The economic } \\
\text { commitment }\end{array}$} & $\begin{array}{l}\text { High school and } \\
\text { the following }\end{array}$ & 98 & 1.543 & 0.235 & \multirow{4}{*}{0.946} \\
\hline & junior college & 75 & 1.622 & 0.157 & \\
\hline & University degree & 32 & 1.606 & 0.312 & \\
\hline & Graduate or above & 1 & 1.550 & 0.255 & \\
\hline \multirow{4}{*}{$\begin{array}{l}\text { Opportunity } \\
\text { commitment }\end{array}$} & $\begin{array}{l}\text { High school and } \\
\text { the following }\end{array}$ & 98 & 1.672 & 0.206 & \multirow{4}{*}{0.001} \\
\hline & junior college & 75 & 1.921 & 0.163 & \\
\hline & University degree & 32 & 2.190 & 0.264 & \\
\hline & Graduate or above & 1 & 2.610 & 0.127 & \\
\hline \multirow{4}{*}{$\begin{array}{l}\text { Employee } \\
\text { performance }\end{array}$} & $\begin{array}{l}\text { High school and } \\
\text { the following }\end{array}$ & 98 & 1.846 & 0.231 & \multirow{4}{*}{0.022} \\
\hline & junior college & 75 & 1.548 & 0.150 & \\
\hline & University degree & 32 & 1.409 & 0.173 & \\
\hline & Graduate or above & 1 & 1.295 & 0.209 & \\
\hline
\end{tabular}

Note: the mean column value is smaller, and the corresponding level is higher

(3) The single factor analysis of work life

For researching that whether X Company employees work life's impact on organizational commitment and employee performance exist a difference or not, we regard work life as a single variable, and do single factor analysis of organizational commitment and job performance. The results, as shown in the table, can be seen from in table 4. We can see that the employees' work life factor on the organizational commitment and employee performance impact has obvious difference in affective commitment, normative commitment, ideal commitment, opportunity commitment and employee performance. When employees just enter into the enterprise, they are full of hope for the future, so the level on affective commitment and normative commitment is a little high. 
Table 4. single factor analysis of the work life scale

\begin{tabular}{|c|c|c|c|c|c|}
\hline $\begin{array}{l}\text { The research } \\
\text { project }\end{array}$ & Work life & $\begin{array}{l}\text { number of } \\
\text { samples }\end{array}$ & The mean & $\begin{array}{l}\text { The standard } \\
\text { deviation }\end{array}$ & $\begin{array}{l}\text { The } \\
\text { significant }\end{array}$ \\
\hline \multirow{4}{*}{$\begin{array}{l}\text { Affective } \\
\text { commitment }\end{array}$} & the following year & 51 & 1.701 & 0.559 & \multirow{4}{*}{0.000} \\
\hline & One to five years & 80 & 1.973 & 0.762 & \\
\hline & In five to ten years & 64 & 2.094 & 1.011 & \\
\hline & More than a decade & 11 & 2.683 & 1.162 & \\
\hline \multirow{4}{*}{$\begin{array}{l}\text { Normative } \\
\text { commitment }\end{array}$} & the following year & 51 & 1.346 & 0.454 & \multirow{4}{*}{0.015} \\
\hline & One to five years & 80 & 1.526 & 0.492 & \\
\hline & In five to ten years & 64 & 1.739 & 0.534 & \\
\hline & More than a decade & 11 & 1.990 & 0.685 & \\
\hline \multirow{4}{*}{$\begin{array}{l}\text { Ideal } \\
\text { commitment }\end{array}$} & the following year & 51 & 2.008 & 0.793 & \multirow{4}{*}{0.045} \\
\hline & One to five years & 80 & 1.906 & 1.026 & \\
\hline & In five to ten years & 64 & 1.731 & 0.925 & \\
\hline & More than a decade & 11 & 1.922 & 1.011 & \\
\hline \multirow{4}{*}{$\begin{array}{l}\text { The economic } \\
\text { commitment }\end{array}$} & the following year & 51 & 1.766 & 0.920 & \multirow{4}{*}{0.341} \\
\hline & One to five years & 80 & 1.720 & 1.013 & \\
\hline & In five to ten years & 64 & 1.764 & 0.911 & \\
\hline & More than a decade & 11 & 1.772 & 0.862 & \\
\hline \multirow{4}{*}{$\begin{array}{l}\text { Opportunity } \\
\text { commitment }\end{array}$} & the following year & 51 & 1.613 & 0.672 & \multirow{4}{*}{0.004} \\
\hline & One to five years & 80 & 1.735 & 0.629 & \\
\hline & In five to ten years & 64 & 1.997 & 0.926 & \\
\hline & More than a decade & 11 & 2.102 & 1.114 & \\
\hline \multirow{4}{*}{$\begin{array}{l}\text { Employee } \\
\text { performance }\end{array}$} & the following year & 51 & 1.910 & 0.138 & \multirow{4}{*}{0.046} \\
\hline & One to five years & 80 & 2.061 & 0.082 & \\
\hline & In five to ten years & 64 & 1.680 & 0.116 & \\
\hline & More than a decade & 11 & 2.349 & 0.151 & \\
\hline
\end{tabular}

Note: the mean column value is smaller, and the corresponding level is higher

(4) The single factor analysis of jobs

For researching that whether $\mathrm{X}$ company employees' jobs' impact on organizational commitment and employee performance exist a difference or not, we regard jobs as a single variable, and do single factor analysis of organizational commitment and job performance. The results, as shown in the table, can be seen from in table 5. We can see that there are significant differences in affective commitment and ideal commitment for different position staffs. 
Table 5. single factor analysis of the jobs scale

\begin{tabular}{|c|c|c|c|c|c|}
\hline $\begin{array}{l}\text { The research } \\
\text { project }\end{array}$ & jobs & $\begin{array}{l}\text { number of } \\
\text { samples }\end{array}$ & The mean & $\begin{array}{l}\text { The standard } \\
\text { deviation }\end{array}$ & $\begin{array}{l}\text { The } \\
\text { significant }\end{array}$ \\
\hline \multirow{4}{*}{$\begin{array}{l}\text { Affective } \\
\text { commitment }\end{array}$} & Ordinary employees & 139 & 1.996 & 0.624 & \multirow{4}{*}{0.001} \\
\hline & First-line managers & 51 & 1.843 & 0.113 & \\
\hline & Middle managers & 12 & 1.591 & 0.198 & \\
\hline & Top managers & 4 & 1.492 & 0.268 & \\
\hline \multirow{4}{*}{$\begin{array}{l}\text { Normative } \\
\text { commitment }\end{array}$} & Ordinary employees & 139 & 1.605 & 0.540 & \multirow{4}{*}{0.824} \\
\hline & First-line managers & 51 & 1.672 & 0.121 & \\
\hline & Middle managers & 12 & 1.620 & 0.169 & \\
\hline & Top managers & 4 & 1.592 & 0.176 & \\
\hline \multirow{4}{*}{$\begin{array}{l}\text { Ideal } \\
\text { commitment }\end{array}$} & Ordinary employees & 139 & 2.350 & 0.206 & \multirow{4}{*}{0.020} \\
\hline & First-line managers & 51 & 1.916 & 0.127 & \\
\hline & Middle managers & 12 & 1.864 & 0.165 & \\
\hline & Top managers & 4 & 1.381 & 0.264 & \\
\hline \multirow{4}{*}{$\begin{array}{l}\text { The economic } \\
\text { commitment }\end{array}$} & Ordinary employees & 139 & 1.731 & 0.573 & \multirow{4}{*}{0.778} \\
\hline & First-line managers & 51 & 1.790 & 0.131 & \\
\hline & Middle managers & 12 & 1.752 & 0.153 & \\
\hline & Top managers & 4 & 1.730 & 0.292 & \\
\hline \multirow{4}{*}{$\begin{array}{l}\text { Opportunity } \\
\text { commitment }\end{array}$} & Ordinary employees & 139 & 1.867 & 0.307 & \multirow{4}{*}{0.592} \\
\hline & First-line managers & 51 & 1.900 & 0.132 & \\
\hline & Middle managers & 12 & 1.873 & 0.146 & \\
\hline & Top managers & 4 & 1.896 & 0.325 & \\
\hline \multirow{4}{*}{$\begin{array}{l}\text { Employee } \\
\text { performance }\end{array}$} & Ordinary employees & 139 & 1.687 & 0.625 & \multirow{4}{*}{0.835} \\
\hline & First-line managers & 51 & 1.703 & 0.160 & \\
\hline & Middle managers & 12 & 1.690 & 0.164 & \\
\hline & Top managers & 4 & 1.689 & 0.322 & \\
\hline
\end{tabular}

Note: the mean column value is smaller, and the corresponding level is higher

\subsubsection{The questionnaire correlation analysis}

The so-called correlation analysis is the study analyzing whether or not there is some kind of interdependent relationship between the phenomena. And the study explores the related direction and the related degree in specific phenomenon. So the so-called correlation analysis is a statistical method of studying random variables relationship. Correlation analysis can show whether or not there is a relationship between the factors and the relationship and show the close degree. The higher the two relations between the two variables are, the higher related degree is. Inputting the following questionnaire data for a vicariate correlation analysis in SPSS19.0, the results such as table 6: 
Table 6. the correlation analysis of organizational commitment and employee performance

\begin{tabular}{l|l|l|l|l|l}
\hline $\begin{array}{l}\text { The research } \\
\text { project }\end{array}$ & $\begin{array}{l}\text { Affective } \\
\text { commitment }\end{array}$ & $\begin{array}{l}\text { Normative } \\
\text { commitment }\end{array}$ & $\begin{array}{l}\text { Ideal } \\
\text { commitment }\end{array}$ & $\begin{array}{l}\text { Economic } \\
\text { commitment }\end{array}$ & $\begin{array}{l}\text { Opportunity } \\
\text { commitment }\end{array}$ \\
\hline $\begin{array}{l}\text { Employee } \\
\text { performance }\end{array}$ & $0.002^{* *}$ & $0.640^{* *}$ & $0.735^{* *}$ & $0.603^{* *}$ & $-0.264^{* *}$ \\
\hline
\end{tabular}

Note: $* * \mathrm{P}<0 . \mathrm{O} 1$ at 0.01 levels (double side) significant correlation

Through the correlation analysis, we can find X company's employee performance and organizational commitment of employees, normative commitment, ideal commitment, economic commitment are positive correlation. However, opportunity commitment is negatively related to the performance opportunity. For affective commitment, in addition to the individual characteristics within the scope of the employees' affective commitment and related performance, the relationship degree of affective commitment and employee performance is not obvious. At the same time the result also shows that $\mathrm{X}$ company employee's organizational commitment level is not high.

\subsubsection{The questionnaire regression analysis}

Import the data into SPSS19.0 by using binary logistic regression analysis, and make organizational commitment all dimensions be an independent variable, make employee performance be the dependent variable, the results such as table 7:

Table 7. the regression analysis table of employee performance

\begin{tabular}{|c|c|c|c|c|c|}
\hline \multirow{2}{*}{$\begin{array}{l}\text { Research } \\
\text { projects }\end{array}$} & \multicolumn{2}{|c|}{ unstandardized coefficient } & \multirow{2}{*}{$\begin{array}{l}\begin{array}{l}\text { standardized } \\
\text { coefficient }\end{array} \\
\text { beta }\end{array}$} & \multirow{2}{*}{$\mathrm{t}$} & \multirow{2}{*}{ significant } \\
\hline & $\begin{array}{l}\text { Regression } \\
\text { coefficient B }\end{array}$ & $\begin{array}{l}\text { standard } \\
\text { deviation }\end{array}$ & & & \\
\hline $\begin{array}{l}\text { Affective } \\
\text { commitment }\end{array}$ & 0.487 & 0.062 & 0.476 & 6.012 & 0.000 \\
\hline $\begin{array}{l}\text { Ideal } \\
\text { commitment }\end{array}$ & 0.174 & 0.079 & 0.473 & 2.211 & 0.028 \\
\hline $\begin{array}{l}\text { The economic } \\
\text { commitment }\end{array}$ & 0.530 & 0.082 & 0.346 & 6.273 & 0.000 \\
\hline $\begin{array}{l}\text { Opportunity } \\
\text { commitment }\end{array}$ & -0.176 & 0.054 & -0.176 & -3.183 & 0.002 \\
\hline
\end{tabular}

From table 7,we can see that: the regression coefficient of affective commitment, ideal commitment, and economic commitment is positive and significant is less than 0.05 , which shows that affective commitment, ideal commitment, economic commitment have significant positive effect on employee performance. The regression coefficient of opportunity commitment is negative and significant is $0.002<0.05$, so the opportunity commitment has significant negative effect on employee performance. And normative commitment is not a list because normative commitment has no significant effect on employee performance.

\section{Conclusions and suggestions}

\subsection{Conclusions}

The article uses the single factor analysis of variance method to analyze these factors, such as the employee's gender, education, working life and jobs, and analyze the various factors influence on organizational commitment and employee performance. Then, we did the correlation analysis for the questionnaire data and conclude that: the organization normative commitment, ideal commitment, and economic commitment are positively correlated, and the opportunity commitment is a negatively correlation. The emotional commitment is not obvious, except that few employees' emotional commitment is related with the employee performance. X company's employee's organizational commitment level is not high.

\subsection{Suggestions}

From the above analysis, we can see that the employee's organizational commitment has a certain impact on employee performance. In the increasingly competitive economic environment, the analysis about how to improve the staff's organizational commitment, so as to improve the employee performance, is very meaningful. Therefore, $\mathrm{X}$ 
Company can adopt the following suggestions when developing human resources strategy:

(1) To strengthen the enterprise culture construction of employees

By the analysis: ideal commitment has significant positive effect on employee performance. To improving employee performance, it is necessary to improve the staff's ideal commitment level. The enterprise culture is the value widely accepted by members, and it has good cohesion function on improve the solidarity of members. In enterprises, using the employees "family management" will let the staff feel the warmth of family, so that we can make consistent with the values and the enterprise staff, which is conducive to the realization of the enterprise performance. So in the enterprise we must strengthen enterprise culture construction, and perfect the system of the enterprise culture.

(2) Establish an effective compensation incentive system

By the analysis: economic commitments have significantly positive effects on employee performance. Economic commitment, therefore, is an important factor to improve the performance. We should establish an effective compensation incentive system to stimulate employees.

First of all, pay system must obey the enterprise's development strategic planning. Organizations in different stages of development, has its different development strategy and different profitability and profitability prospects, and these differences will lead to different compensation strategy. Second, there are differences in the positioning of the enterprise's salary, so as to be able to effectively motivate employees, improve the level of opportunity commitment, and raise the level of employee performance.

(3) To establish the perfect training system

By the analysis: the different education and work life have significant differences to opportunity commitment, and opportunity commitment has a negative impact on employee performance. Therefore, the decrease of enterprise employee's opportunity commitment is very important to improve employee performance.

Marlow's hierarchy of needs theory, points out that people have various needs, and the highest need is self-development and self-realization. Self-development and self-realization demand come from the heart, such as staff level of education, career, jobs, etc., especially the need for skills training .These training related with employees interests tend to be more popular when compared to other trainings. Then trainees' learn ideas will change, from "want me to learn" into "I want to learn", and the learning attitude will be more active. Therefore, the effectiveness of the training can be improved.

(4) Establish humanized performance management system

By the analysis: the level of employee performance determines the performance of enterprise. So we should formulate human performance management system, with employees as the core, and make the performance management system suitable for the enterprise development.

(5) Strengthen the employee's career management

By the analysis: different employees' personality traits have different effects on organizational commitment and employee performance. So we should treat different employees by using different ways of management. In order to encourage employees to work positively, we should make a particular employee career management.

Enterprise can make surveys about employees through the "Chinese employees" organizational commitment questionnaire. By the surveys, we can understand the employee's organizational commitment level, and get together the staff's personal development direction and development of enterprise vision, to design different career development plan for employees. At the same time, it can also improve the employee performance, which is conducive to the long-term development of the enterprise.

\section{References}

Becker, H. S. (1966). Notes on the Concept of Commitment, American Journal of Sociology, 1966, (132).

Bruce Buchanan. (1974). Government Management, Business Executive and Organizational Commitment. Public Administration Review, 1974, 34(4). http://dx.doi.org/10.2307/975244

Fishbein M. (1967). Attitude and the prediction of behavior. InM. Fishbein (Ed.), Readings in attitude theory and measurement. New York: Wiley.

FishbeinM, AjzenI. (1975). Belief, attitude, intention and behavior. Reading, Mass: Addison-Wesle.

J.P .Meyer, N.J. Allen. (1997). Commitment the Workplace: Theory, Research, and application. Sage Publications Inc. 
L.M.Porter.R.M. Steers, R.T. (1974). Nowday. Organizational Commitment, Job satisfaction and Turnover among Psychiatic Technicians. Journal of Applied Psychology, 1974, 59.

MathieuJ E,Zajac D. (1990). A Review and meta-analysis of the antecedents, correlates, and consequences of organizational commitment. Psychological $\quad$ Bulletin, $\quad 194$. http://dx.doi.org/10.1037/0033-2909.108.2.171

Meyer J P, Allen NJ, Smith CA. (1993). Commitment to organizations and occupations. Extension and test of a three-component conceptualization. Journal of Applied Psychology, 1993(78):538- 551. http://dx.doi.org/10.1037/0021-9010.78.4.538

Meyer J P, Allen NJ. (1990). The measurement and antecedents of affective, continuance and normativec commitment to the organization. Journal of Occupational Psychology, 1990 (63): 1- 18.

Meyer J.P. Allen NJ. (1991). A Three-component Conceptualization of Organizational Commitment. Human Resource Man—agent Review, 1991, (1): 64-98.

Mowday RT, Steers R, Porter L. (1976). The measurement of organizational commitment. Journal of Vocational Behavior, 1976(14) :224- 247.

P.C.Morrow. (1983). Concept Redundancy in Organization Research: The Case of Work Commitment. Academy of Management Review, 1983, 8(3).

Porter L, Crampon W, Smith F. (2003). Organizational commitment and managerial turnovers: Alongitudinal study. Organizational Behavior and Human Performance, 2003,15.

Porter LW, Steers RM, MowdayRT, et al. (1974). Organizational commitment, job satisfaction, and turnover among psychiatric technicians. Journal of Applied Psychology, 1974 (59):603- 609. http://dx.doi.org/10.1037/h0037335

Sheng Tan, Wensuan Ling. (2002). The validation about the five factors model of Chinese employees' organizational commitment. Journal of Guangzhou university, 2002, (6): 96-99(in Chinese).

Y. Wiener. (1982). Commitment In Organization: a normative view. The Academy of Management Review, 1982, $7(3)$.

Yi Han. (2007). The research about influence of organizational commitment on employees work performance, $A t$ Zhong nan university of economics and law journal, 2007(03): 56(in Chinese) 


\section{Appendix: organizational commitment and employee performance survey scale}

Hello! First, please forgive us for disturbing your work and rest.

This is an academic questionnaire which is aimed to figure out the relationship between organizational commitment and employee performance, to develop a suitable human resource strategy and be useful for company's further development. Since the truthfulness of your answers to the questions has very important effect on my research, please answer them truly.

This investigation is carried out by secret ballot. All information will be analyzed statistically and absolutely confidential. So please feel no pressure completing it. After finishing it, please hand in to the principal of each department.

Your support will be the key to his research and the strategy formulation. Thanks again for your help! Wish you good health and work!

Note: in the next 15 minutes please answer the question sincerely and select your answer on the right side or tick it.

1. Please select the proper option given your condition.

1) your gender: A male $B$ female Age

2) your education background: A high school or beneath $B$ vocational school $C$ University $D$ Graduate or above

3) your working experience : A under one year B 1-5 years C 5-10 years $D$ above 10 years

4) your occupation: A staff $\mathrm{B}$ basic managing level $\mathrm{C}$ middle level manager $\mathrm{D}$ senior manager

2. The following will be focused on some descriptions of organizational commitment. Please select a proper option base on your real condition.

1) I am willing to work in the current company

A strongly agreed B agree C doesn't matter or don't know D disagree E strongly disagree

2) I won't leave even if the company benefits become poor

A strongly agreed B agree C doesn't matter or don't know D disagree E strongly disagree

3) I think we should love our company as our home

A strongly agreed B agree C doesn't matter or don't know D disagree E strongly disagree

4) I am proud to be one of the company staff

A strongly agreed B agree $\mathrm{C}$ doesn't matter or don't know D disagree $\mathrm{E}$ strongly disagree

5) I am willing to contribute all I have to the company

A strongly agreed B agree $\mathrm{C}$ doesn't matter or don't know D disagree $\mathrm{E}$ strongly disagree

6) I think the frequent change of job is immoral

A strongly agreed B agree C doesn't matter or don't know D disagree E strongly disagree

7) The job I have fulfill me and make me feel sense of achievement

A strongly agreed $\mathrm{B}$ agree $\mathrm{C}$ doesn't matter or don't know D disagree $\mathrm{E}$ strongly disagree

8) I think we are obligated to the development of company

A strongly agreed B agree C doesn't matter or don't know D disagree E strongly disagree

9) My family will suffer loss if I leave the company

A strongly agreed B agree C doesn't matter or don't know D disagree E strongly disagree

10) Even if I want to leave the company, it is actually very hard to do it

A strongly agreed B agree C doesn't matter or don't know D disagree E strongly disagree

11) Without specialty, changing job is hard for me

A strongly agreed B agree C doesn't matter or don't know D disagree E strongly disagree

12) The current company has very important effect on me fulfilling myself

A strongly agreed B agree $\mathrm{C}$ doesn't matter or don't know D disagree $\mathrm{E}$ strongly disagree 
13) The reason why I still stay is that it's hard to find another appropriate job

A strongly agreed $\mathrm{B}$ agree $\mathrm{C}$ doesn't matter or don't know D disagree $\mathrm{E}$ strongly disagree

14) I think working hard is one way to pay back the company

A strongly agreed B agree C doesn't matter or don't know D disagree E strongly disagree

15) I stayed because there are plenty room for me to develop

A strongly agreed B agree C doesn't matter or don't know D disagree E strongly disagree

16) The company can provide me many training opportunities

A strongly agreed B agree C doesn't matter or don't know D disagree E strongly disagree

17) I will do my best to do the job

A strongly agreed B agree C doesn't matter or don't know D disagree E strongly disagree

18) I won't do my job until last minute

A strongly agreed B agree C doesn't matter or don't know D disagree E strongly disagree

19) I feel I need more training

A strongly agreed B agree C doesn't matter or don't know D disagree E strongly disagree

20) I only do what I have to do

A strongly agreed B agree C doesn't matter or don't know D disagree E strongly disagree

21) I find working exhausting

A strongly agreed B agree C doesn't matter or don't know D disagree E strongly disagree

22) I often do other things which are not my job

A strongly agreed B agree C doesn't matter or don't know D disagree $\mathrm{E}$ strongly disagree

23) I have good relationship with my colleagues and often help them with their job

A strongly agreed B agree C doesn't matter or don't know D disagree E strongly disagree

24) I initiative do my job

A strongly agreed B agree C doesn't matter or don't know D disagree E strongly disagree

25) I am _ with my payment

A strongly agreed B agree C doesn't matter or don't know D disagree E strongly disagree 